THE CUCHULAIN PLAYS OF W. B. YEATS 


\section{The Cuchulain Plays of W. B. Yeats:}

A Study

\section{Reg Skene}

Director of Theatre and Associate Professor of English University of Winnipeg 
(C) Reg Skene 1974

Softcover reprint of the hardcover 1st edition 1974 All rights reserved. No part of this publication may be reproduced or transmitted, in any form or by any means, without permission.

First published 1974 by THE MACMILLAN PRESS LTD

London and Basingstoke Associated companies in New York Dublin Melbourne Johannesburg and Madras

SBN 333166043

ISBN 978-1-349-02222-9

ISBN 978-1-349-02220-5 (eBook) DOI 10.1007/978-1-349-02220-5

Typeset by COLD COMPOSITION LTD Southborough, Tunbridge Wells 


\section{TO ANNETTE}




\section{Contents}

$\begin{array}{rrr} & \text { Introduction } & \text { ix } \\ & \text { Acknowledgements } & \text { xiii } \\ 1 & \text { The Ritual of a Lost Faith } & 1 \\ 2 & \text { That Famous Man Cuchulain } & 16 \\ 3 & \text { The Burning Wheel of Love } & 38 \\ 4 & \text { The Rag-and-Bone Shop of the Heart } & 72 \\ 5 & \text { Players and Painted Stage } & 86 \\ 6 & \text { The Sudden Cry of a Hawk } & 124 \\ 7 & \text { A High, Wide, Foxy Man } & 146 \\ 8 & \text { Between a Fool and a Blind Man } & 154 \\ 9 & \text { The Fifteenth Night } & 201 \\ 10 & \text { What Stood in the Post Office? } & 222 \\ & \text { Notes } & 241 \\ & \text { Select Bibliography } & 265 \\ & \text { Index } & 272\end{array}$




\section{Introduction}

W. B. Yeats wrote five plays about the Irish hero Cuchulain. The first written, On Baile's Strand, was completed in 1903 and was performed on the stage of the Abbey Theatre in December 1904. Yeats made major revisions of the play for performance in 1906, after which he declared:

It is now as right as I can make it with my present experience, but it must always be a little over-complicated when played by itself. It is one of a cycle of plays dealing with Cuchulain, with his friends and enemies. One of these plays will have Aoife as its central character, and the principal motive of another will be the power of the witches over Cuchulain's life. The present play is a kind of cross-road where too many interests meet and jostle for the hearer to take them in at a first hearing unless he listen carefully, or know something of the story of the other plays of the cycle. ${ }^{1}$

Yeats' next Cuchulain play was a prose play, The Golden Helmet, which was produced in 1908 . Yeats completed a revised version, this time in verse and bearing the title The Green Helmet, in 1910. He said in a note: 'The play is founded upon an old Irish story, The Feast of Bricriu, given in Cuchulain of Muirthemne, and is meant as an introduction to On Baile's Strand. ${ }^{2}$

In 1917 and 1919, Yeats completed two additional plays, At the Hawk's Well and The Only Jealousy of Emer, basing them on the model of Japanese Noh drama. He said of them: “ "At the Hawk's Well" and "The Only Jealousy of Emer" are the first and last plays of a series of four dealing with Cuchulain's life. The others are my "Green Helmet" and "Baile's Strand".,3 Although he spoke of the cycle as being complete and gathered the plays into their proper sequence 
as a play cycle in the 1934 edition of Collected Plays, Yeats realised that the series was not yet finished. He wrote in 1934: 'I would have attempted the Battle of the Ford and the Death of Cuchulain, had not the mood of Ireland changed." 4

Late in the year 1938, his own death near, Yeats undertook to complete his Cuchulain cycle. On 1 January, 1939, he wrote to Edith Shackleton Heald: 'I think my play is strange and the most moving I have written for some years. I am making a prose sketch for a poem - a kind of sequel strange too, something new.' ${ }^{\text {Th }}$ The play Yeats referred to was The Death of Cuchulain, the poem, 'Cuchulain Comforted'. Yeats died four weeks later.

It is clear from his comments that Yeats intended his Cuchulain plays to make up a coherent and unified play cycle. Yeats' clearly expressed intent in this regard has most often been ignored both by producers and critics. Having staged the plays in a single-evening production in 1969, I am convinced that the major patterns of meaning in the plays become apparent only when they are considered together. It was this conviction which prompted the approach taken in the present study.

Because the Cuchulain plays were central to so much of Yeats' life and work, they do indeed provide a 'kind of cross-road' where Yeats' main interests 'meet and jostle'. In the first half of this book, I consider the Cuchulain plays in the context of five of Yeats' main areas of interest. Chapter 1 traces the relationship between the Cuchulain plays and Yeats' desire to regenerate Ireland by means of an Irish Mystical Order. Chapter 2 considers the Cuchulain plays as an outgrowth of the Celtic revival and of the nationalist movements which grew out of that revival. Chapter 3 relates the plays to that system of wheels and moon phases which Yeats wrote about in $A$ Vision. Chapter 4 examines the biographical elements in the plays. Chapter 5 treats Yeats' theatrical theories and the impact of these theories on the form of the Cuchulain plays. The last five chapters are devoted to an examination of the text of each of the five plays in turn. Particular attention is given to those patterns of meaning which emerge only when the plays are considered together. 
In the course of this study, I have felt at no time any inclination to take a patronising attitude towards Yeats' work in the theatre. All evidence seems to point to the fact that as a practical theatre worker he was innovative, pragmatic and highly skilled. I suspect that the period of greatest respect for Yeats' theatrical ideas and for his accomplishments as a playwright is yet to come. In the past ten years the discovery of Artaud, the influential work of such directors as Grotowski and Brook, the renewed interest in Gordon Craig have served to make the public aware that there are exciting alternatives to naturalism in the theatre. We may be on the threshold of a period when Yeats' subjective, lyrical drama will no longer be out of phase. If Yeats were to begin to get the careful and competent professional productions he has generally been denied in our time, it would become increasingly difficult to ignore the fact that he was in actuality a highly successful playwright working in a difficult and not always popular form.

It was T. S. Eliot who most clearly described the nature and importance of Yeats' accomplishment as a playwright.

Yeats had nothing, and we have had Yeats. He started writing plays at a time when the prose-play of contemporary life seemed triumphant, with an indefinite future stretching before it; when the comedy of light farce dealt only with certain privileged strata of metropolitan life; and when the serious play tended to be an ephemeral tract on some transient social problem. . . . Just as, from the beginning, he made and thought his poetry in terms of speech and not in terms of print, so in the drama he always meant to write plays to be played and not merely to be read. . . . It is impossible to disentangle what he did for the Irish theatre from what the Irish theatre did for him. From this point of vantage, the idea of the poetic drama was kept alive when everywhere else it had been driven underground. I do not know where our debt to him as a dramatist ends - and in time, it will not end until that drama itself ends. ${ }^{6}$

It was Eliot also who pointed out that Yeats was the first contemporary writer to use myth as a criticism of modern life by 'manipulating a continuous parallel between contem- 
poraneity and antiquity'. 'Instead of narrative method, we may now use the mythical method. It is, I seriously believe, a step toward making the modern world possible for art . . .7 Nowhere can this method be seen to be operating more effectively than in the Cuchulain plays. 


\section{Acknowledgements}

The author and publishers wish to thank the following for permission to reproduce copyright material: Columbia University Press for the extracts from The Tragic Drama of William Butler Yeats by Leonard E. Nathan and from the first volume of W. B. Yeats: Uncollected Prose edited by John P. Frayne; Faber \& Faber Ltd and E. P. Dutton \& Co. Inc. for the extracts from Yeats: The Man and the Masks by Richard Ellmann; the Hamlyn Publishing Group Ltd for the extracts from The New Larousse Encyclopedia of Mythology; William Heinemann Ltd for the extract from On the Art of the Theatre by Edward Gordon Craig; John Murray (Publishers) Ltd for the extract from Cuchulain of Muirthemne by Lady Gregory; the Bulletin of the New York Public Library for the extracts from 'The Reception of Synge's Playboy in Ireland and America, 1907-1912' by Daniel J. Murphy; Thames \& Hudson Ltd and Praeger Publishers Inc. for the extracts from The Celts by T. G. E. Powell; M. B. Yeats, Miss Anne Yeats and Hart-Davis MacGibbon Ltd for the extract from Letters of $W$. B. Yeats edited by Allan Wade; M. B. Yeats, Miss Anne Yeats, the Macmillan Co. of Canada and Macmillan Publishing Co. Inc., New York, for 'Easter 1916' from Collected Poems of W. B. Yeats. 